\title{
The Emergence of Novel-Coronavirus and its Replication Cycle - An Overview
}

\author{
Hafiz M.N. Iqbal' ${ }^{*} \mathbb{D}$, Kenya D. Romero-Castillo ${ }^{1} \mathbb{D}$, Muhammad Bilal ${ }^{2} \mathbb{D}$ \\ and Roberto Parra-Saldivar ${ }^{1}$ (D)
}

${ }^{1}$ Tecnologico de Monterrey, School of Engineering and Sciences, Campus Monterrey, Ave. Eugenio Garza Sada 2501, Monterrey, N.L., CP 64849, Mexico. ${ }^{2}$ School of Life Science and Food Engineering, Huaiyin Institute of Technology, Huaian 223003, China.

\begin{abstract}
Recently, a new viral-based infection has emerged as a respiratory disease caused by a novel (new) coronavirus that was first detected in Wuhan City, China. With any or many reasons, this newly emerged novel-Coronavirus (2019-nCoV) has now been recognized in more than 70 locations around the globe. The disease caused by 2019-nCoV has been named as "coronavirus disease 2019 - COVID-19". Due to the rising number of confirmed 2019-nCoV infected cases and widespread detection, the World Health Organization (WHO) has announced 2019-nCoV as a threatening health concern, and urgent robust actions are of supreme interest to tackle this global health emergency. Owing to this new emergence, we know relatively little about 2019-nCoV, which is a highly pathogenic human pathogen. To completely overcome this life-threatening 2019-nCoV pathogen, further in-depth studies are needed to gain insight and complete understanding about its fast mode spread, replication, and pathogenesis. Since the first appearance and detection of 2019-nCoV and COVID-19, respectively, the current literature lacks the global perspective and replication cycle of 2019-nCoV. Thus, herein, an effort has been made to cover this literature gap. A proper understanding of the 2019-nCoV replication will further insight and strengthen the infection control measures, transmission prevention, and vaccine development, effectively.
\end{abstract}

Keywords: 2019-nCoV, COVID-19, Emergence, Infection, Respiratory disease, Replication

*Correspondence: hafiz.iqbal@tec.mx; Tel.: +52 (81) 83582000 ext. 5679.

(Received: February 29, 2020; accepted: March 08, 2020)

Citation: Hafiz M. N. Iqbal, Kenya D. Romero-Castillo, Muhammad Bilal and Roberto Parra-Saldivar, The Emergence of NovelCoronavirus and its Replication Cycle - An Overview, J. Pure Appl. Microbiol., 2020; 14(1):13-16. https://doi.org/10.22207/ JPAM.14.1.03

(C) The Author(s) 2020. Open Access. This article is distributed under the terms of the Creative Commons Attribution 4.0 International License which permits unrestricted use, sharing, distribution, and reproduction in any medium, provided you give appropriate credit to the original author(s) and the source, provide a link to the Creative Commons license, and indicate if changes were made. 


\section{INTRODUCTION}

\section{The emergence of 2019-nCoV}

The appearance of a new viral outbreak from Wuhan City, China, in Hubei Province, named as 2019-nCoV has now turned into a global concern. Owing to the rising number of infected cases and widespread detection of 2019-nCoV, the International Health Regulations Emergency Committee of the World Health Organization (WHO) declared the 2019-nCoV outbreak a "public health emergency of international concern
(PHEIC) on 30 January 2020. Previous outbreaks of coronavirus such as severe acute respiratory syndrome (SARS) (SARS-CoV) (Hui and Zumla, 2019) or Middle Eastern respiratory syndrome (MERS) (MERS-CoV) (Al-Tawfiq et al., 2013) both left 774 and 850 deaths respectively, reflect the severity of the threat and urgency to resolve this outbreak as soon as possible.

The transmissibility of 2019-nCoV, or at least its geographical distribution, seems to be higher and broader than expected due to
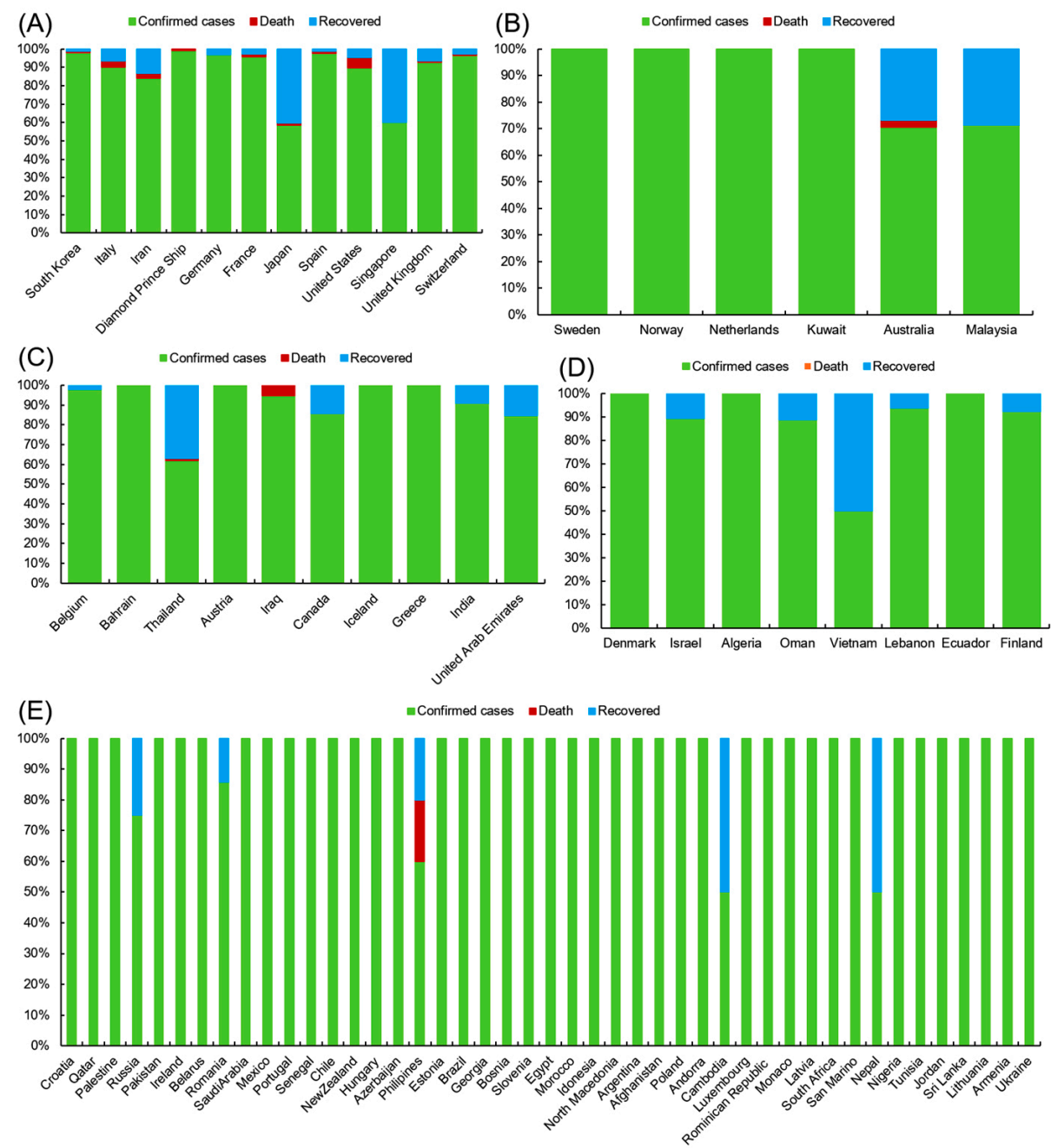

Fig. 1. Recent stats on global emergence and worldwide confirmed 2019-nCoV cases in different countries. The data is distributed based on the confirmed cases range, i.e., (A) more than 100 confirmed 2019-nCoV cases, (B) confirmed 2019-nCoV cases in the range between 51-100, (C) confirmed 2019-nCoV instances in the range between 26-50, (D) confirmed 2019-nCoV cases in the range between 11-25, and (E) confirmed 2019-nCoV cases in the range between 1-10. Data Source: IFENG News. Available online at the link: https://jobtube.cn/ wv/?from=singlemessage\&isappinstalled=0 [Last accessed date: 6 March 2020]. 
the vast transport network used in China. It is anticipated that more cases will be spread to other countries and that further transmission may occur, regardless of the initial source of 2019-nCoV still remains unknown. Several studies have reported that although uncounted of the first confirmed cases of 2019-nCoV in China worked or visited the Huanan market. Based on the preliminary findings, these factors have been identified. The Huanan seafood market located in Wuhan City is the first and most important reason (World Health Organization (WHO), 2020). On the other hand, the market has remained closed since January 1, 2020. As of March 5, 2020, a total of 80581 confirmed 2019-nCoV cases along with 522 suspected cases had been reported in China. Recent stats on the emergence and widespread distribution of novel-Coronavirus (2019-nCoV) in different provinces of CHINA are summarized in Table 1. Whereas, current stats on the appearance and worldwide 2019-nCoV cases in different countries are shown in Figure 1. In order to overcome this health contingency, it is necessary to take the corresponding measures. For instance, the timely detention of the trade-in suspected animals of Wuhan City. Likewise, trade routes must be monitored from the site of the outbreak as well as identify the animals responsible for the infection and the development of additional control and prevention strategies.

\section{Replication cycle of 2019-nCoV}

The recently reemerged 2019-nCoV is an enveloped positive-sense RNA virus. It is characterized by club-like spikes projecting from its surface (Phan, 2020). Coronavirus is a complex pathogen with a high capability to infect multiple host species (Fung et al., 2019). Thus, cause a variety of diseases with numerous symptoms. A mechanistic representation of endocytosis and exocytosis-based Coronavirus entry and exit to and from the host, respectively, is shown in Figure 2. The main steps involved in the replication cycle are (1) binding and 2019-nCoV entry to the host via membrane fusion or endocytosis mechanism, (2) upon entrance to the host, release of viral genome, (3) translation of viral polymerase protein, (4) RNA replication, (5) sub-genomic transcription, (6) translation of viral structural protein, (7) viral structural proteins combine with nucleocapsid, (8) formation of mature virion, and (9) release of

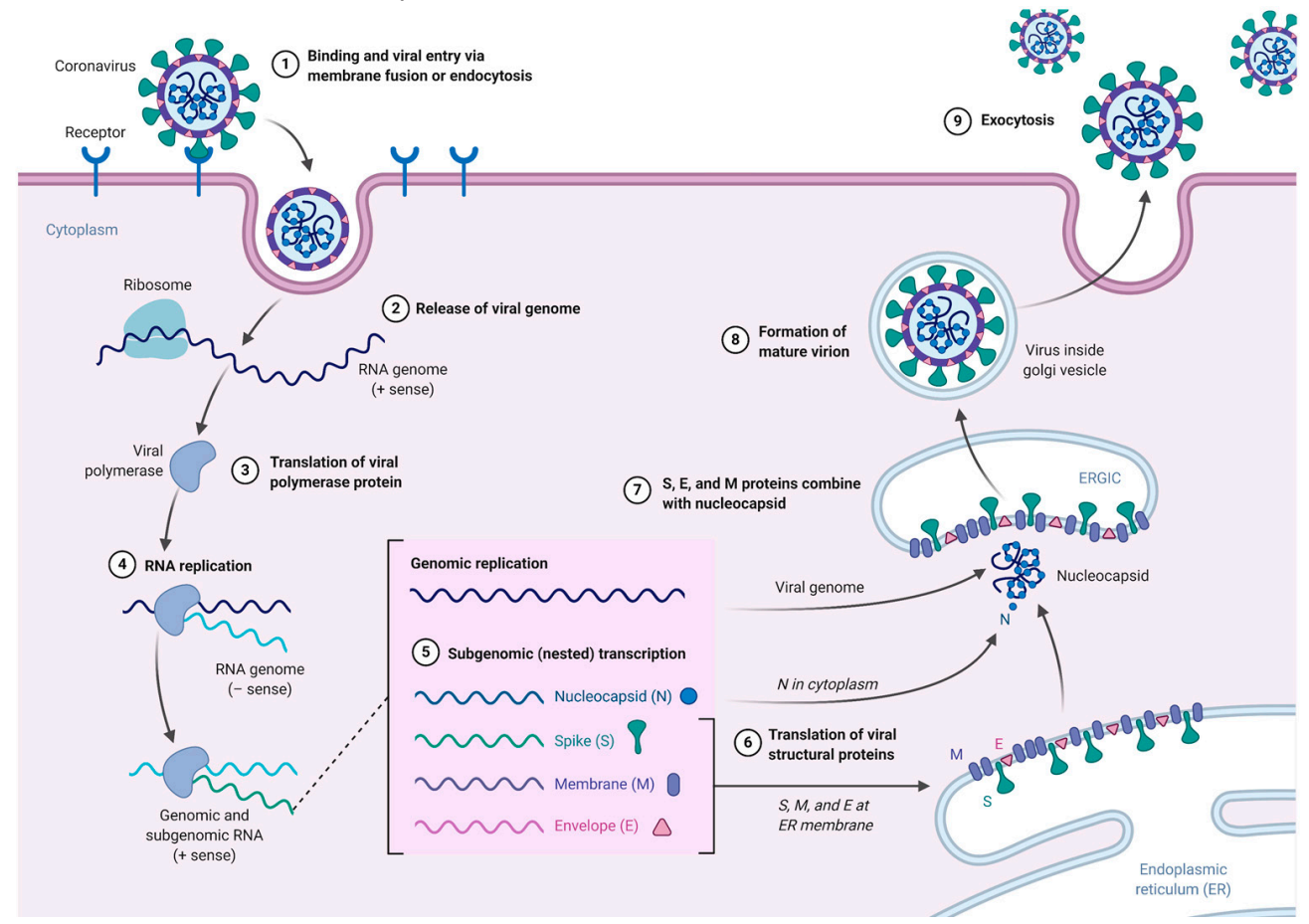

Fig. 2. Representation of endocytosis and exocytosis-based Coronavirus entry and exit to and from the host, respectively. The Figure was created with "BioRender.com" template and exported under the terms of premium subscription 
Table 1. Recent stats on the emergence and widespread distribution of novel-Coronavirus (2019-nCoV) in different provinces of CHINA. Data Source: IFENG News. Available online at the link:https://jobtube.cn/wv/? from $=$ singlemessage \&isapp installed $=0$ [Last accessed date: 6 March 2020].

\begin{tabular}{|c|c|c|c|}
\hline Province & $\begin{array}{c}\text { Confirmed } \\
\text { cases }\end{array}$ & Death & Recovered \\
\hline Hubei & 67466 & 2902 & 40479 \\
\hline Guangdong & 1351 & 7 & 1181 \\
\hline Henan & 1272 & 22 & 1239 \\
\hline Zhejiang & 1215 & 1 & 1130 \\
\hline Hunan & 1018 & 4 & 933 \\
\hline Anhui & 990 & 6 & 956 \\
\hline Jiangxi & 935 & 1 & 901 \\
\hline Jiangsu & 631 & & 580 \\
\hline Chongqing & 576 & 6 & 502 \\
\hline Shandong & 758 & 6 & 566 \\
\hline Sichuan & 539 & 3 & 418 \\
\hline Heilongjiang & 481 & 13 & 379 \\
\hline Beijing & 418 & 8 & 297 \\
\hline Shanghai & 339 & 3 & 303 \\
\hline Fujian & 296 & 1 & 270 \\
\hline Hebei & 318 & 6 & 301 \\
\hline Shaanxi & 245 & 1 & 224 \\
\hline Guangxi & 252 & 2 & 213 \\
\hline Hainan & 168 & 6 & 158 \\
\hline Yunnan & 174 & 2 & 169 \\
\hline Guizhou & 146 & 2 & 114 \\
\hline Shanxi & 133 & & 126 \\
\hline Liaoning & 125 & 1 & 106 \\
\hline Tianjin & 136 & 3 & 128 \\
\hline Gansu & 102 & 2 & 87 \\
\hline Jilin & 93 & 1 & 86 \\
\hline Inner Mongolia & 75 & 1 & 64 \\
\hline Xinjiang & 76 & 3 & 69 \\
\hline Ningxia & 75 & & 69 \\
\hline Qinghai & 18 & & 18 \\
\hline Tibet & 1 & & 1 \\
\hline Hong Kong & 105 & 2 & 43 \\
\hline Taiwan & 44 & 1 & 12 \\
\hline Macao & 10 & & 9 \\
\hline
\end{tabular}

mature virion via exocytosis mechanism. At the end of the cycle, the newly released mature virion can further infect a new target, and it continues consecutively.

\section{Concluding remarks}

Owing to this new emergence, we know fairly little about 2019-nCoV. However, as evident from the current WHO announcement about 2019$\mathrm{nCoV}$ as a global health emergency, 2019-nCoV is a highly pathogenic human pathogen. To completely overcome this life-threatening 2019-nCoV pathogen, further in-depth studies are needed to gain insight and complete understanding about its fast mode spread, replication, and pathogenesis.

\section{ACKNOWLEDGMENTS}

All listed author(s) are thankful to their representative universities/institutes for providing the related support to compile this work.

\section{CONFLICT OF INTEREST}

The listed author(s) declare no conflict of interest in any capacity, including competing or financial.

\section{AUTHORS' CONTRIBUTION}

All listed author(s) have made a substantial, direct and intellectual contribution to the work, and approved it for publication.

\section{FUNDING}

This study received no external funding.

\section{ETHICS STATEMENT}

This article does not contain any studies with human participants or animals performed by any of the authors.

\section{AVAILABILITY OF DATA \\ Not applicable.}

\section{REFERENCES}

1. Al-Tawfiq, J. A., Assiri, A., \& Memish, Z. A. Middle East respiratory syndrome novel corona (MERS-CoV) infection. Saudi Med J, 2013; 34(10), 991-994.

2. Fung, T. S., \& Liu, D. X. Human Coronavirus: HostPathogen Interaction. Annual Review of Microbiology, 2019; 73; 529-557. https://doi.org/10.1146/annurevmicro-020518-115759

3. Hui, D. S., \& Zumla, A. Severe Acute Respiratory Syndrome: Historical, Epidemiologic, and Clinical Features. Infectious Disease Clinics, 2019; 33(4), 869889. https://doi.org/10.1016/j.idc.2019.07.001

4. Phan, T. Novel coronavirus: From discovery to clinical diagnostics. Infection, Genetics and Evolution, $2020 ; 79,104211$. https://doi.org/10.1016/j. meegid.2020.104211

5. World Health Organization (WHO), 2020. Emergencies preparedness, response, Pneumonia of unknown origin - China Disease outbreak news 5 January, Available at: https://www.who.int/csr/don/05january-2020-pneumonia-of-unkown-cause-china/ en/. [Last Accessed date: 6 March 2020]. 